4. Дягилев Р. А. Макросейсмика техногенных землетрясений Урала // Горный информационноаналитический бюллетень (научно-технический журнал). - 2017. - № 3. - С. 292-304.

5. СП 269.1325800.2016 Транспортные сооружения в сейсмических районах. Правила уточнения исходной сейсмичности и сейсмического микрорайонирования. Дата введения 2017-06-17. - М., 2016. - 77 с.

6. Уломов В.И., Шумилина Л.С. Проблемы сейсмического районирования территории России. - М.: ВНИИНТПИ Госстроя России, 1999. - 56 с.

7. Шебалин Н.В. Методы использования инженерно-сейсмологических данных при сейсмическом районировании // Сейсмическое районирование СССР. - М., 1968. - С. 95-111.

\title{
ПРОЯВЛЕНИЕ ФРАНСКО-ТУРНЕЙСКИХ РИФОГЕННЫХ МАССИВОВ В ПЛОТНОСТНОМ СТРОЕНИИ ВЕРХНЕЙ ЧАСТИ РАЗРЕЗА СОЛИКАМСКОЙ ВПАДИНЫ
}

\author{
Г.П. Щербинина \\ Горный институт УрО РАН, г. Пермь
}

\begin{abstract}
Аннотация: Гравиметрической съемкой, проводимой на Верхнекамском месторождении калийных солей (Соликамская впадина Предуральского прогиба), установлено, что породные толщи верхней части разреза обладают плотностной неоднородностью, не связанной с литологией. Картины плотностной неоднородности обусловлены разными причинами. Одна из них, формирующая закономерный рисунок в расположении локальных аномалий - присутствие франско-турнейских рифогенных массивов. Гравиметрическая съемка показала, что в верхней части осадочного чехла по контуру франско-турнейских массивов наблюдаются локальные разуплотненные участки в виде цепочек. Снижение плотности на локальных участках достигает $2 \%$.
\end{abstract}

Ключевые слова: гравиметрия, плотность пород, рифогенный массив, плотностная картина.

Франско-турнейская карбонатная толща в Соликамской впадине Предуральского прогиба залегает на глубинах от 1.8 до 2.5 км. Выше по разрезу на глубине 200-700 м располагается толща солей, к которой приурочено Верхнекамское месторождение калия. Франско-турнейская толща содержит рифовые постройки с размерами в поперечнике 5-6 км. Они имеют преимущественно изометричную форму в плане и сложены органогенными карбонатами, обладающими жестким каркасом и характе-

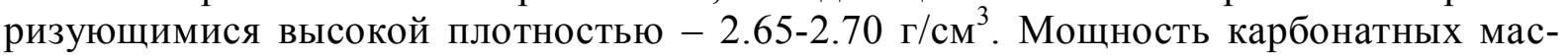
сивов достигает 500-550 м. Синхронная им слоистая толща представлена межрифовыми отложениями - обломочными карбонатами, глинистыми и битуминозными карбонатами, характеризующимися средней пониженной плотностью $\left(2.37-2.45 \mathrm{r} / \mathrm{cm}^{3}\right)$. Межрифовые отложения за счет глинистой составляющей в продолжение геологической истории при накоплении перекрывающих отложений уплотнялись. Эффект уплотнения проявился в сокращении их мощности и формировании в вышележащих толщах над рифами структур облекания, которые являются в данном регионе основными нефтесодержащими структурами. Современная мощность франскотурнейской толщи в межрифовых пространствах на Березниковском палеоплато составляет 300-350 м. В соседних с палеоплато впадинах мощность франскотурнейской толщи 150-200 м.

Период уплотнения межрифовых осадков растянулся на продолжительное время. Например даже в подошве соляной лунежской толщи над рифовыми массивами в настоящее время наблюдаются структуры облекания, хотя и слабо выраженные.

Плотностное гравиметрическое моделирование показало, что перекрывающие толщи карбона и перми над франско-турнейскими рифогенными массивами характеризуются 
также повышенной плотностью по сравнению с окружающими участками. Таким образом, рифы и структуры их облекания представляют в палеозойском разрезе столб плотных пород.

Влияние жестких рифогенных массивов и структур их облекания на геодинамическую обстановку в Соликамской впадине проявлялось и после накопления лунежской толщи солей. Это доказывается тем, что франско-турнейские массивы влияли на перераспределение накопившихся соляных масс. В виду того, что каменные соли являются весьма пластичным материалом, их первичное горизонтальное залегание и слабо меняющаяся толщина позже были нарушены под действием региональных тектонических сил, вызвавших явления галокинеза [1]. В настоящее время четко заметен эффект уменьшения мощности соляной толщи в области рифогенных построек и увеличения ее в межрифовых пространствах. Так, на территории южнее Дуринской системы впадин над Сибирским, Уньвинским, Березниковским массивами мощность толщи от ОГ «С» (подошва лунежской соли) до кровли покровной каменной соли составляет 370-400 м. В пределах межрифовых участков мощность достигает 470-520 м.

Сложное напряженно-деформированного состояние и деструкция толщ на участках сочленения жестких карбонатных массивов и окружающих пространств обусловили появление здесь микротрещиноватых зон и развитие физико-химических преобразований пород [2].

Влияние франско-турнейских массивов и структур их облекания на физикомеханическое состояние пород наблюдается на современном этапе геологической истории. Многие элементы речной сети в Соликамской впадине подчиняются строению рифосодержащей толщи. Влияние проявляется также в особенностях современного плотностного строения верхней части геологического разреза. Бортовые зоны рифогенных структур представляют контакт разномодульных сред, где в условиях Предуральского прогиба формируются дополнительные напряжения, что вызывает вторичные изменения пород. В некоторых солеразведочных скважинах, пробуренных в пределах бортовых зон, зафиксированы брекчированность пород, выщелачивание, деформированность, запах битума. Концентрация случаев проявления вторичных изменений пород в областях сочленения рифогенных массивов и окружающих толщ свидетельствует о большей интенсивности происходивших здесь процессов механического разрушения и химических преобразованиях пород. Этим обусловлена повышенная неоднородность плотностных свойств толщ вдоль границ рифогенных массивов.

Примером является Белопашнинский рифогенный массив, выявленный на Палашерском участке в южной части калийной залежи. На разностных трансформантах гравитационного поля, характеризующих плотностное строение надсоляной толщи, над Белопашнинским массивом зафиксирована концентрическая система локальных отрицательных аномалий, отражающих наличие разуплотненных участков.

На рис. 1 приведено сечение трехмерной трансформанты гравитационного поля через Белопашнинскую структуру. Представляющие плотное тело франско-турнейский массив и структуры его облекания проявляются в картине гравитационной трансформанты положительной интенсивной аномалией Б. Локальные участки разуплотненных пород на периферии карбонатного тела, окружающие массив, отражаются в виде отрицательных аномалий 1 и 2. Наиболее резко разуплотненные области проявляются в верхней части разреза, в надсоляной и соляной толщах.

Картина кольцевого расположения разуплотнений на разностных трансформантах гравитационного поля зафиксирована и на северном окончании Легчимского рифогенного массива (восток БКПРУ-4). Здесь в пределах одного из разуплотнений про- 
бурена скважина 459, где надсоляной разрез носит следы постседиментационных изменений: в известняково-мергельной толще встречены прослои с обломками известняка, в нижней части соляно-мергельной толщи и в верхней части переходной пачки отмечается деформированность слоев, выраженная в крутых углах падения слоистости, до 60-90.

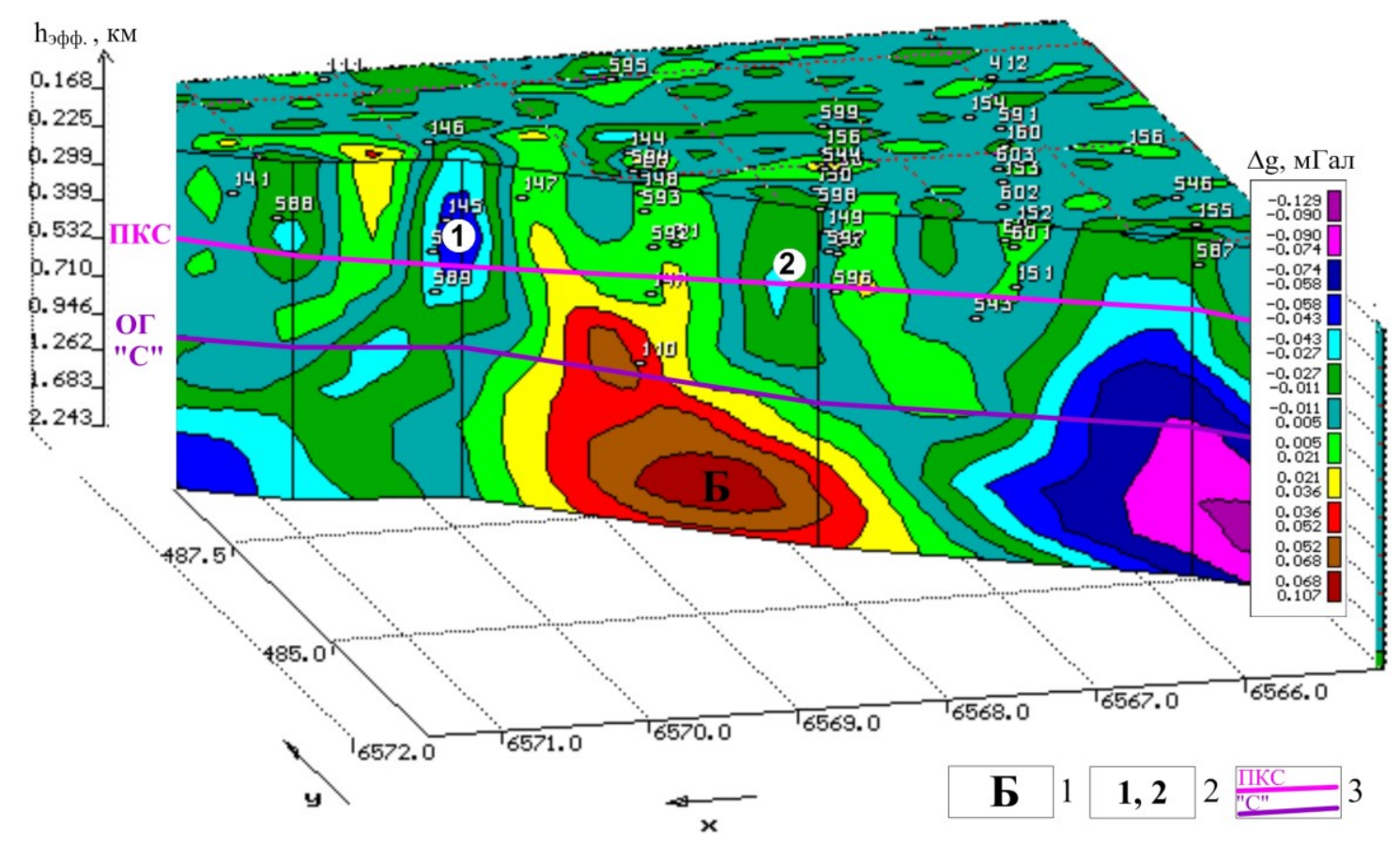

Рис. 1. Вертикальные сечения трехмерной трансформанты гравитационного поля.

1 - положительная аномалия, отражающая наличие плотной карбонатной постройки $\mathrm{D}_{3} \mathrm{fr}-\mathrm{C}_{1} \mathrm{t}$ возраста;

2 - отрицательные аномалии в верхней части разреза, окаймляющие карбонатную постройку;

3 - положение кровли покровной каменной соли и подошвы соляной толщи (ОГ «С») на шкале эффективных глубин трансформанты

По данным гравитационного моделирования степень разуплотнения пород на таких участках может достигать $1.5-2 \%$.

Таким образом, на Верхнекамском месторождении калийных солей в условиях Соликамской впадины наблюдается влияние франско-турнейских рифогенных массивов на плотностную картину в осадочном чехле. Бортовые зоны массивов являются областями повышенной неоднородности плотностных свойств соляной и надсоляной толщ. Здесь наблюдаются локальные участки разуплотнения пород, организованные в кольцевые структуры в соответствии с контуром рифогенных структур. Степень выраженности кольцевой неоднородности различна на разных участках и у разных рифогенных массивов.

\section{Работа выполнена при поддержке гранта РФФИ № 19-45-590011р_а}

\section{БИБЛИОГРАФИЧЕСКИЙ СПИСОК}

1. Петротектонические основы безопасной эксплуатации Верхнекамского месторождения калийномагниевых солей / под ред. Н.М. Джиноридзе. - СПб; Соликамск, 2000. - 400 с.

2. Щербинина Г.П. Исследование причин обрушения пород на втором Соликамском руднике Верхнекамского месторождения солей по геолого-геофизическим данным / Г.П. Щербинина / Геофизические методы поисков и разведки месторождений нефти и газа: межвуз. сб. науч. тр. / ПГУ. - Пермь, 1998. - C. 85-96. 